от струевого пламени, прямое огневое воздействие при распространении пламени по облаку газовоздушной смеси.

При полном разрушении сосудов под давлением опасность представляют разлетающиеся фрагменты корпуса и воздушная ударная волна. Из «обрезанных» при разрушении сосуда концов его входного и выходного патрубков возникает истечение высокоскоростных струй газа, либо взаимодействующих, либо не взаимодействующих, которые могут воспламениться, с развитием либо струевого пожара, либо пожара в загроможденном пространстве. Утечка нестабильного конденсата сопровождается его интенсивным испарением и образованием взрывоопасного облака тяжелого газа, которое стелется по поверхности площадки и в условиях плотной технологической застройки недостаточно быстро рассеивается. При появлении источника зажигания в зоне взрывоопасных концентраций газа облако воспламеняется, сгорая по дефлаграционному типу, но с достаточно высокими скоростями распространения фронта горения. При этом возникает воздушная волна сжатия с избыточным давлением и импульсом на фронте волны, способными повредить здания и технологическое оборудование на площадке УКПГ[1]. При этом, наиболее опасным представляется разрушение обвязки ректификационной колонны иразрушение загрузочного трубопровода во время операции перегрузки метанола из мобильных контейнеров в стационарные емкости склада метанола.

Учитывая возможные причины аварий на УКПГ, можно вовремя их предупредить, избежав нежелательных последствий.

$$
* * *
$$

1. Руководство по безопасности «Методика анализа риска аварий на опасных производственных объектах нефтегазодобычи» от 17 августа 2015 г. № 317. [Электронный ресурс]. - Режим доступа: http://docs.cntd.ru/document/1200124162 (Дата обращения 07.11.2017 г.).

\title{
Смирнов А.Н., Алексеев Д.И. \\ Совершенствование СМК коксохимических предприятий, направленное на удовлетворение требований потребителей, с учётом бизнес-процессов металлургических комбинатов
}

Магнитогорский государственный технический университет им Г. И. Носова doi:10.18411/spc-12-11-2017-18

(Россия, Магнитогорск)

idsp: 000001:spc-12-11-2017-18

Большинство коксохимических предприятий России входят в состав металлургических комбинатов: НТМК, ЗСМК, КМК, ММК, Северсталь, Уральская сталь, - и их основной продукцией является кокс. Показателями качества кокса с точки зрения основного потребителя (доменного производства) являются механическая прочность M25 и истираемость M10, а также зольность $\mathrm{Ad}, \%$ и содержание серы $\mathrm{Sd}, \%$ которые контролируются отдельно. С точки зрения бизнес-процесса на металлургическом комбинате, необходимо обеспечивать снижение затрат на производство конечной продукции, в том числе и за счёт снижения стоимости промежуточных продуктов, в частности при производстве кокса.

В советские годы плановой экономики каждое из предприятий, коксохимическое и доменное, рассматривались в отдельности, задачей коксохимического предприятия был выпуск стабильного высококачественного кокса по показателям M25 и M10, отвечающего стандарту, и целой гаммы химических 
продуктов. Доменное производство, в свою очередь, было нацелено на эффективное использование высококачественного кокса. Металлургический комбинат был обязан выдать определённый или больший объём продукции. После перехода России к рыночной модели экономики, что означало признание философии международных стандартов на основе TQM (Total Quality Management), введения на многих предприятиях СМК, коксохимическое предприятие не сумело сориентироваться на потребителе и, одновременно, на потребностях металлургического комбината, который стал самостоятельной коммерческой единицей. По оценкам экспертов, при существующей организации доменного процесса высококачественный кокс по показателям M25 и М10удовлетворяет доменные производства, но не удовлетворяет металлургические комбинаты с точки зрения бизнес-процесса в целом, так как затраты на такой кокс себя не окупают. Снижение себестоимости кокса связано, как правило, с ухудшением качества кокса по показателям M25 и M10, что не удовлетворяет доменное производство, так как использование такого кокса снижает производительность доменной печи, и может остановить доменный процесс, что недопустимо[1].

Исследователями для различных металлургических комбинатов были созданы математические модели для прогнозирования показателей качества кокса М25 и M10 и, используя определенный критерий оптимальности качества кокса, найдены соответствующие уровни качества кокса. Из литературных данных известно, что себестоимости, соответствующие найденным оптимальным уровням качества кокса, не удовлетворили металлургические комбинаты и не были приняты к производству. Данная ситуация сложилась потому, что использовавшиеся критерии оптимальности, вероятно, удовлетворяли советским плановым потребностям коксохимического и доменного производств, с дополнительными ограничениями на стоимость шихты, без учёта детального влияния показателей качества кокса M25 и M10 на доменный процесс и ориентации на бизнес-процесс на металлургических комбинатах в целом. Результатами подобных работ даже не стало, к сожалению, включение и мониторинг в СМК коксохимических производств тех параметров, которые влияют на показатели качества кокса M25 и М10[2]. Фактически, в настоящее время, как следует из открытых источников, в СМК коксохимических производств отсутствуют положение о том, каким образом необходимо достигать каких-либо требуемых потребителем параметров качества кокса[1].

В связи с вышеизложенным, совершенствования СМК коксохимических производств, исходя из уровня качества кокса, востребованного у потребителя (доменное производство) и находящегося в согласии с бизнес-процессом металлургических комбинатов, является актуальной задачей. Реализация данной цели требует формулирования соответствующего критерия оптимальности и нахождения уровня качества кокса по показателям M25 и M10, в зависимости от параметров, влияющих на их значения. Важность данного направления также обуславливается и тем, что во второй половине 2017 года заканчивается срок действия сертификатов соответствия СМК многих коксохимических предприятий России, что диктует необходимость в новой сертификации и переосмыслении существующих СМК.

$$
* * *
$$

1. Актуальные проблемы современной науки, техники и образования: материалы 74-й международной научно-технической конференции / под ред. В.М. Колокольцева. Магнитогорск: Изд-во Магнитогорск.гос. техн. ун-та им. Г.И. Носова, 2016. Т.1. 289 с.

2. Смирнов А.Н., Алексеев Д.И. Сопоставление и анализ адекватности математических моделей для прогнозирования показателей качества кокса M25 И M10 // Вестник Магнитогорского государственного технического университета им. Г.И. Носова. 2017. Т.15. №3. С. 62-67. 